Access to Justice in Eastern Europe,

Issue 1 (6) 2020 10.33327/AJEE-18-3.1

ISSN 2663-0575 (Print)

ISSN 2663-0583 (Online)

http://ajee-journal.com

A Gołąb 'Recent Developments in Polish Civil Procedure in the Field of Public Hearing' (2020) 1(6) Access to Justice in Eastern Europe 46-57.

10.33327/AJEE-18-3.1-a000025

Received 10.11.2019

Revised 20.12.2019

Approved 22.01.2019

\title{
RECENT DEVELOPMENTS IN POLISH CIVIL PROCEDURE IN THE FIELD OF PUBLIC HEARING
}

\author{
Agnieszka Gołab \\ Ph.D., Assistant Professor, Chair of Civil Procedure, \\ Warsaw University, Poland
}

Doi 10.33327/AJEE-18-3.1-a000025

Summary: 1. Introduction. -2 . The Right to a Public Hearing in the Light of the ECHR's and the Polish Constitutional Tribunal's Case Law. - 3. The Grounds for Passing a Judgment in Camera According to the Polish Code of Civil Procedure. - 4. Passing Procedural Decisions outside of a Public Hearing. - 5. Conclusion.

The present paper deals with the possibility of passing judgments on merit and procedural decisions at a court session held in camera. In order to assess the admissibility of this practice and its congruence with constitutional standards, the article presents the relevant case law of the European Court of Human Rights and the Polish Constitutional Tribunal. The paper discusses the issue of the 'right to a public hearing' in connection with the recent amendment of the Polish Code of Civil Procedure, which widened the court's possibility to pass judgments and decisions in chambers.

Keywords: right to a public hearing, case law, passing judgment in camera, passing decisions outside of a public hearing. 


\section{INTRODUCTION}

The Polish Code of Civil Procedure has recently been subject to one of the vastest amendments since its enactment in $1964 .{ }^{1}$ The legislative action was aimed at simplifying and accelerating court proceedings. ${ }^{2}$ In order to fulfill this goal, the lawmaker resolved to reform selected aspects of civil procedure, which in his view hindered the effective course of the proceedings and a relatively quick adjudication of the case. Some of these changes affect the right to a public hearing, which is significant considering the prominent role of this fundamental procedural right. The right to a public hearing, proclaimed by Article 6 (1) ECHR as well as by constitutional acts such as Article 45 (1) of the Constitution of the Republic of Poland, is widely regarded as one of the pillars of contemporary civil procedure. ${ }^{3}$ The right to a public hearing as a general concept exerts an impact on many specific procedural solutions. While characterizing this concept it is possible to differentiate its external (Germ. Volksöffentlichkeit) and internal (Germ. Parteiöffentlichkeit) aspect. ${ }^{4}$ The former facilitates participation of the public at a hearing, which prevents the court from adjudicating a civil case in secret, without the public control of the media and the audience. ${ }^{5}$ This issue is regulated in Article $9 \$ 1$ sentence 1 in principio of the Polish Code of Civil Procedure (hereinafter: PCCP) ${ }^{6}$ and Article $148 \$ 1$ in fine PCCP. More specifically it deals with third parties' access to a court hearing, providing them with a possibility of following the course of a civil action and learning about the outcome of the case. It strengthens the transparency of the court's activities and increases the public's trust in the judicial process. ${ }^{7}$ According to Article 45 (2) sentence 2 of the Constitution of the Republic of Poland, the external aspect of the

$1 \quad$ The Act of 4 July 2019 on the amendment of the Polish Code of Civil Procedure and other laws [2019] Polish Journal of Laws, item 1469 (Ustawa z dnia 4.07.2019 r. o zmianie ustawy - Kodeks postępowania cywilnego oraz niektórych innych ustaw [2019] Dz.U. poz. 1469).

2 Cf. the written explanation accompanying the Government's bill on the amendment of the Polish Code of Civil Procedure and other laws, Sejm's legislative materials no 3137.

3 Cf. W Miszewski, 'Jawność w procesie cywilnym w związku z przepisami kodeksu postępowania cywilnego' (1933) 1 Polski Proces Cywilny 11-12; K Stefko, 'Główne zasady polskiej procedury cywilnej' (1929) 1 PPiA 23; E Waśkowski, System procesu cywilnego. Wstęp teoretyczny (Vilnius 1932); J Skąpski, Postępowanie. Część ogólna, in: Polska procedura cywilna. Projekty referentów z uzasadnieniem (Cracow 1921); S Kruszelnicki, 'Zasady procesu cywilnego według polskiej procedury cywilnej' (1931) 9 Głos Sądownictwa 476; W Miszewski, Proces cywilny w zarysie (Łódź 1946); A Kościółek, Zasada jawności w sądowym postępowaniu cywilnym (WK 2018); W Broniewicz, 'Jawność jako konstytucyjna zasada procesu cywilnego Polski Ludowej' (1954) 5-6 NP 83; K Gajda-Roszczynialska, 'Zasada jawności w postępowaniu cywilnym' (2013) 1 Iustitia 11; T Stawecki, 'Jawność jako wartość prawa' (2004) 43 Studia Iuridica 217; P Rylski, T Zembrzuski, 'Rozpoznawanie spraw cywilnych na posiedzeniu niejawnym' (2006) 6 Przegląd Sądowy 84-85; Z Miczek, 'Jawność posiedzeń sądowych w postępowaniu cywilnym i jej wyłączenia' (2005) 6 Ius et Administratio 85; J Gudowski, 'Laserunkowość postępowania cywilnego' in A Laskowska-Hulisz, J May, M Mrówczyński (eds), Honeste procedere. Księga jubileuszowa dedykowana Profesorowi Kazimierzowi Lubińskiemu (WK 2017).

4 Cf. K Weitz, 'Commentary to article 9 PCCP' in T Ereciński (ed), Komentarz KPC (Warsaw 2016) vol 1, point 1 .

5 The German and Swiss doctrine uses the concept 'keine Geheimjustiz. Cf. WH Rechberger, DA Simotta, Grundriss des österreichischen Zivilprozessrechts. Erkenntnisverfahren (MANZ 2010); FC Mayer, in U Karpenstein, FC Mayer (eds), Konvention zum Schutz der Menschenrechte und Grundfreiheiten. Kommentar (CH Beck 2015), art 6, p 178; T Sutter-Somm, B Seiler, in T Sutter-Somm, F Hasenböhler, C Leuenberger (eds), Kommentar zur Schweizerischen Zivilprozessordnung (ZPO) (Schulthess 2016) art 54, p 455.

6 Polish Code of Civil Procedure of 17 November 1964 with amendments [1964] Polish Journal of Laws, no 43 , item 296 with amendments.

7 Rechberger, Simotta (n 5) 234; Mayer (n 5) 178; Sutter-Somm, Seiler (n 5) 455; Gudowski (n 3 ) 120. 
right to a public hearing can be excluded only under exceptional circumstances which include: the regard for morality, the safety of the State, public order, the protection of privacy of the parties or other important private interest. ${ }^{8}$

By contrast the internal aspect of the right to a public hearing is directed towards the procedural relationship of the parties and the court. It constitutes the inherent component of the right to be heard ${ }^{9}$ and is consequently an indispensable part of the procedural justice. ${ }^{10}$ It manifests itself in the parties' right to be notified of the court sessions, the possibility of presenting their own standpoint, acquainting themselves with the stance of their opponent and participating in the court's activities. The internal aspect of the right to a public hearing can be neither limited nor excluded because it would lead to the invalidity of civil proceedings (cf. article 379 PCCP). ${ }^{11}$

\section{THE RIGHT TO A PUBLIC HEARING IN THE LIGHT OF THE ECHR'S AND THE POLISH CONSTITUTIONAL TRIBUNAL 'S CASE LAW}

The assessment of legislative solutions, which limit the right to a public hearing, should be preceded by an analysis of the standards and requirements elaborated by the European Court of Human Rights (cf. art. 6 (1) sentence 1 ECHR - 'everyone is entitled to a fair and public hearing') and the relevant case law of the Polish Constitutional Tribunal on article 45 (1) of the Constitution of the Republic of Poland. According to the European Court of Human Rights, the right to a public hearing is endangered, if the lawsuit is examined in written proceedings and the party does not have any legal instruments to have her case heard in the public and oral court session. ${ }^{12}$ This scenario is likely to occur, when the lack of a public hearing cannot be redressed at the later

$8 \quad$ P Grzegorczyk, K Weitz, 'Commentary to art. 45 of the Constitution of the Republic of Poland', in M Safjan, L Bosek (eds) Konstytucja RP (2016) vol 1, nb 108. Cf. also Gudowski (n 3) 119-120. Cf. Art. 45 (2) sentence 1 of the Constitution of the Republic of Poland.

9 On the links between the internal aspect of the right to a public hearing and the right to a fair trial $-\mathrm{cf}$. P Hofmański, 'Prawo do sądu w ujęciu Konstytucji i ustaw oraz standardów prawa międzynarodowego' in L Wiśniewski (ed), Wolności i prawa jednostki oraz ich gwarancje w praktyce (Wydawnictwo Sejmowe 2006).

10 As the Polish Constitutional Tribunal indicated in its judgement of 31 March 2005, SK 26/02, OTK-A, 2005 , no 3 , item 29 , the term of procedural fairness does not have a strictly specified meaning. However, different concepts procedural fairness have a common core containing: 1) the right to be heard;2) a clear manifestation of the motives of the verdict, thus avoiding any arbitrariness in the court's decisions in a way allowing for the verification of the court's reasoning; 3) guaranteeing foreseeability to the parties of the proceedings, by assuring cohesion and internal logic of the procedural mechanisms. Cf. Judgement of the Polish Constitutional Tribunal of 16.1.2006, SK 30/05, OTK-A 2006, no 1, item 2; of 2.10.2006, SK 34/06, OTK-A 2006, no 9, item 118; of 20.11.2007, SK 57/05, OTK-A 2007, no 10, item 125; of 26.02.2008, SK 89/06, OTK-A 2008, no 1, item 7; of 12.01.2010, SK 2/09, OTK-A 2010, no 1, item 1; of 18.10.2011, SK 39/09, OTK-A 2011, no 8, item 84; of 8.04.2014, SK 22/11, OTK-A 2014, no 4, item 37.

11 Rechberger, Simotta (n 5) 234-235. Cf also Miszewski, 'Jawność w procesie cywilnym w związku z przepisami kodeksu postępowania cywilnego' (n 3) 17-18; Gajda-Roszczynialska, 'Commentary to art. 9 PCCP' in A Góra-Błaszczykowska (ed), Komentarz KPC (CH Beck 2013) point 45; Weitz'Commentary to art. 9 PCCP' (n 4) point 4. Under exceptional circumstances the internal aspect of the right to a public hearing must be correlated with the regard for the safety of the State, which may have a negative influence on the way and scope of informing parties about the course of the proceedings and the collected means of evidence - cf. Grzegorczyk, Weitz (n 8), and the ECHR case law cited in this publication.

12 Weber $v$ Switzerland [1990] ECHR judgement of 22.5.1990, no 11034/84, , point 39; $46 \mathrm{ff}$. In literature Mayer (n 5) 178. 
stage of the proceedings. ${ }^{13}$ When the case is to be examined only in the course of one instance proceedings, the Strasbourg court accepts the lack of a public hearing only under exceptional circumstances. ${ }^{14}$ The public hearing can be foregone, if at a certain point of the civil process the court deals exclusively with strictly formal, legal or technical issues, which have nothing or little to do with the sphere of examining facts and conducting evidence proceedings. ${ }^{15}$ The European Court of Human Rights has held that the principle of procedural justice is not infringed, if the judgment was passed in written proceedings, as long as the goal of legal protection in the framework of a given civil process does not require holding a public hearing (for a second time), ${ }^{16}$ the party to the proceedings already had an opportunity to present her stance in a different manner than at the oral hearing. ${ }^{17}$ Although the ECHR presents a rather restrictive approach in its case law, it nonetheless accepts the fact that conducting a public hearing should not be regarded as a goal in itself. ${ }^{18}$ While examining this issue, it is important to assess to what extent the lack of a public hearing could have impacted on the outcome of the case. While analyzing this issue, it should be borne in mind that examining the case by the first instance court at the public hearing diminishes the intensity of this requirement at the subsequent stages and instances of civil proceedings. ${ }^{19}$ Having said that, a party's right to a public hearing should be safeguarded in at least one stage or instance of the proceedings. ${ }^{20}$ In the light of the Strasbourg court's case law with regard to Article 6 (1) ECHR it is acceptable to conduct a public hearing as late as in the appellate proceedings, similarly as forgoing the right to a public hearing at the appellate stage, if the aforementioned right had already been safeguarded at an earlier part of the civil process. ${ }^{21}$ It needs emphasizing that these remarks hold true, unless the examination of the case at a given stage of the proceedings requires conducting and assessing evidence with the participation of the parties.

While analyzing the procedural guarantees of the publicly conducted judicial process, one should also take into account some equally important values, such as the effectiveness

13 Moser v Austria [2006] ECHR judgement of 21.9.2006, no 12643/02, , point 96. Cf. Mayer (n 5) 179.

14 Cf ECHR judgement of 23.2.1994, no 18928/91, Fredin v Sweden, point. 21; ECHR judgement of 19.2.1998, no 16970/90, Allan Jacobsson v Sweden, point 46.

15 Cf. Axen v Germany [1983] ECHR judgement of 8.12.1983, no 8273/78, point 28; Monnell and Morris $v$ the United Kingdom [1987] ECHR judgement of 2.3.1987, no 9562/81 and 9818/82, point 58; Hoppe $v$ Germany [2002] ECHR judgement of 5.12.2002, no 28422/95, point 64 .

16 Cf. Hoppe v Germany (n 15); Fejde v Sweden [1991] ECHR judgement of 29.10.1991, no 12631/87, point 33; Ekbatani $v$ Sweden [1988] ECHR judgement of 26.5.1988 - 10563/83, point 31-32; Helmers $v$ Sweden [1991] ECHR judgement of 29.10.1991 - 11826/85, point 37 ff.; Kremzow v Austria [1993] ECHR judgement of 21.9.1993, no 12350/86, point $67 \mathrm{ff}$.; Elsholz v Germany [2000] ECHR judgement of 13.7.2000, no 25735/94, point 66; Constantinescu v Romania [2000] ECHR judgement of 27.6.2000, no $28871 / 95$, point 55 .

17 Cf. Schuler-Zgraggen v Switzerland [1993] ECHR judgement of 24.6.1993, no 14518/89, point 58; Döry $v$ Sweden [2002] ECHR judgement of 12.11.2002, no 28394/95, point 37 ff.; Jussila v Finland [2006] ECHR judgement of 23.11.2006 (GK), no 73053/01, point $41 \mathrm{ff}$.

18 Mayer (n 5) 179, point 64.

19 Cf. Miller $v$ Sweden [2005] ECHR judgement of 8.2.2005, no 55853/00, point 30.

20 Cf. Fischer v Austria [1995] ECHR judgement of 26.4.1995, no 16922/90.

21 Cf. Faugel $v$ Austria [2003] ECHR judgement of 20.11.2003, no 58647/00 and 58649/00; Abrahamian v Austria [2008] ECHR judgement of 10.4.2008, no 35354/04; Weber (n 12); Riepan v Austria [2000] ECHR judgement of 14.11.2000, no 35115/97, point 40 ff. Cf. Mayer (n 5) 180-181, point 65, 67. 
and speed of civil proceedings. ${ }^{22}$ The possibility of taking those values into account is nonetheless conditional upon multiple factors, such as the scope of examination of the court at the given stage of the case and the type and subject matter of the proceedings at hand..$^{23}$ It is also worth adding that the European Court of Human Rights accepts the situation when a party renounces its right to a public hearing. ${ }^{24}$ As the court indicates in its case law, neither the letter, nor the spirit of article 6 (1) ECHR prevents a party from not taking advantage or relinquishing the right attributed to her. ${ }^{25}$ Such a renouncement may take place in a direct or implied manner, but it must be unambiguous, and it cannot give room to speculation.

Before discussing amendments introduced to the PCCP by the Act of 4 July 2019 it is also indispensable to refer to the case law of the Polish Constitutional Tribunal on the grounds of article 45 of the Constitution of the Republic of Poland, which regulates the right to a fair and public hearing. As far as the internal aspect of the right to a public hearing is concerned, the scope and shape of respective legislative solutions designed to fulfill it, are conditional upon the procedural positions of the parties, the subject matter of the case, its character and the type of the proceedings. ${ }^{26}$ These solutions must enable a party to learn about the proceedings and its development. Although this aspect of the right to a public hearing is most frequently characterized by a party's right to participate at the court session, it may as well be realized by means of service of judicial documents, court announcements and access to the court files. ${ }^{27}$ The right to be heard - understood as the party's right to present her procedural stance and the possibility of learning about the procedural stance of the opposite party - will be deemed respected, even if it takes place in a written form. ${ }^{28}$

In regard to the external aspect of the right to a public hearing, the strictly literal content of article 45 (1) of the Constitution of the Republic of Poland, similar to article 6 (1) $\mathrm{ECHR}$, does not give basis to qualitatively different stages of the proceedings, when it comes to the guarantee of the right to a public hearing. However, as was shown with regard to article 6 (1) ECHR, a reasonable approach to this issue should be adopted. For instance, fulfilling the requirement of a public hearing in the proceedings before the court of first instance allows for adopting a more lenient approach to this issue in

22 Petersen v Germany [2001] ECHR judgement of 6.12.2001, no 31178/96; Helmers (n 16) point $36 \mathrm{ff}$.

23 C Grabenwarter, Europäische Menschenrechtskonvention (Beck 2008); Mayer (n 5) 180.

24 Cf. Art. 233 of the Swiss ZPO.

25 Cf. Albert and Le Compte v Belgii [1983] ECHR judgement of 10.2.1983, no 7299/75,7496/76, point 35; Schuler-Zgraggen v Szwajcarii [1993] ECHR judgement of 24.6.1993, no 14518/89, point 58; Hakansson and Sturesson $v$ Szwecji [1990] ECHR judgement of 21.2.1990, no 12585/86, point 66; Le Compte ua [1981] ECHR judgement of 23.6.1981, no 6878/75, point 59; Zumtobel v Austria [1993] ECHR judgement of 21.9.1993,no12235/86; Pauger $v$ Austria [1997] ECHR judgement of 28.5.1997, no 16717/90, point 58 i 62; Sejdovic v Italy [2006] ECHR judgement of 1.3.2006, no 56581/00, point 86 $<$ www.echr.coe.int> accessed 18 February 2020. In literature cf. Mayer (n 5) 181, point 69-70.

26 Cf. Judgement of the Polish Constitutional Tribunal of 3.07.2007, SK 1/06, OTK-A, 2007, no 7, item 73.

27 Grzegorczyk, Weitz (n 8) point 97.

28 See judgement of the Polish Constitutional Tribunal of z 11.06.1002, SK 5/02, OTK-A 2002, no 4, item 41; judgement of the Polish Constitutional Tribunal of 6.12.2004, SK 29/04, OTK-A 2004, no 11, item 114; judgement of the Polish Constitutional Tribunal of 2.10.2006, SK 34/06, OTK-A 2006, no 9, point 118; judgement of the Polish Constitutional Tribunal of 19.9.2007, SK 4/06, OTK-A 2007, no 8, item 98; judgement of the Polish Constitutional Tribunal of 20.11.2007, SK 57/05, OTK-A 2007, no 10, item 125; judgement of the Polish Constitutional Tribunal of 20.10.2010, P 37/09, OTK-A 2010, no 8, item 79. 
the course of the appellate proceedings due to its secondary, control-oriented or strictly juridical character. The legislator's decisions whether the case should be examined at a public hearing or not, should also take into account such factors as the subject matter of a case, the type, character and stage of the proceedings as well as the scope of court's control powers under specific circumstances. ${ }^{29}$

The assessment of the solutions adopted by the Act of 4 July 2019 should also be preceded with an analysis, whether the exclusion of the right to a public hearing is congruent with the premises enumerated in article 45 (2) sentence 1 of the Constitution of the Republic of Poland. It is worth adding that a similar issue was regulated in article 6 (1) sentence 2 ECHR.${ }^{30}$ In the written clarifications added by the Polish legislator to the Act of 4 July 2019, it was explained that the motive behind introducing amendments to the PCCP consisted in increasing the speed and effectiveness of the proceedings. ${ }^{31}$ The Polish Constitutional Tribunal and the jurisprudence indicate that these values should be examined in the context of the premise of public order. ${ }^{32}$ These elements are in connection with the right to obtain a verdict without undue delay (iustitiae dilatio est quaedam negatio), which is equally safeguarded by article 45 (1) of the Constitution of the Republic of Poland and consequently, its influence cannot be overlooked when it comes to the interpretation of article 45 (2) sentence 1 of the Constitution of the Republic of Poland. ${ }^{33}$ Therefore, it is possible to draw a preliminary conclusion that the Polish Constitution accepts to a certain extent an examination of civil cases in camera. ${ }^{34}$ Additionally, it is worth mentioning that the European Court of Human Rights holds that the exclusion of a public hearing is supposed to meet the requirements of proportionality. Thus, it will be deemed acceptable as long as a) an exclusion of a public hearing serves the objectives laid out in article 6 (1) sentence 2 ECHR; b) an exclusion of a public hearing truly serves those objectives; c) there is an adequate relation between the grounds of exclusion specified in article 6 (1) sentence 2 ECHR and the reasons against the exclusion; d) it is not possible to fulfill the goals indicated in article 6 (1) sentence 2 ECHR in a different way (i.e. by taking advantage of other means) than by forgoing the public hearing. ${ }^{35}$

29 Grzegorczyk, Weitz (n 8) point 97.

30 Cf. Article 6 (1) sentence 2 ECHR which states that 'the public may be excluded from all or part of the trial in the interests of $(\ldots)$ public order $(\ldots)$, or to the extent strictly necessary in the opinion of the court in special circumstances where publicity would prejudice the interests of justice'.

31 Cf. the written explanation accompanying the Government's bill on the amendment of the Polish Code of Civil Procedure and other laws, Sejm's legislative materials no 3137.

32 Cf. A Kubiak, Konstytucyjna zasada prawa do sadu w świetle orzecznictwa Trybunału Konstytucyjnego (Wydawnictwo Uniwersytetu Łódzkiego 2006); judgement of the Polish Constitutional Tribunal of 26.11.2013, SK 33/12, OTK-A 2013, no 8, item 124. Cf, however, M Skibińska, 'Rozpoznanie i rozstrzygnięcie sprawy cywilnej na posiedzeniu niejawnym na podstawie art. $148^{1} \mathrm{KPC}$ w świetle zasad postępowania cywilnego i treści art. 5 KPC’ in A Barańska, S Cieślak, Ars in vita. Ars in iure. Księga jubileuszowa dedykowana Profesorowi Januszowi Jankowskiemu (CH Beck 2018) 160; M Mączyński, 'Ograniczenie prawa podmiotów gospodarczych do sądu' (2000) 5 PiP 60 ff.; judgment of the Polish Constitutional Tribunal of 2.10. 2006, SK 34/06.

33 T Ereciński, K Weitz, 'Efektywność ochrony prawnej udzielanej przez sądy w Polsce’ (2005) 10 Przegląd Sądowy $14-15$ and 17.

34 Cf. Judgment of the Polish Constitutional Tribunal of 18.2.2009, KP 3/08, OTK-A 2009, no 2, item 9; judgement of the Polish Constitutional Tribunal of 15.4.2009, SK 28/08, OTK-A 2009, no 4, item 48; 7.12.2010, P 11/09, OTK-A 2010, no 10, item 128.

35 P Hofmański, A Wróbel, in L Garlicki (ed), Konwencja o Ochronie Praw Człowieka i Podstawowych Wolności (CH Beck 2010) vol. 1, art. 6, p. 363-364. 
The regard for speed and effectiveness ${ }^{36}$ as an element of the public order does not raise controversy in situations when the court examines in camera strictly formal, procedural, incidental or technical issues. ${ }^{37}$ Nonetheless, some other situations can also be accepted from the constitutional standpoint. For instance, in the light of the abovementioned interpretation of Article 45 (1) sentence 2 of the Constitution of the Republic of Poland, it is acceptable to issue a judgment in camera if a party has conceded the claims of the plaintiff (article $148^{1} \$ 1$ in principio PCCP). ${ }^{38}$ It could even be asserted that as long as the defendant's stance (i.e. the fact of acknowledging the claims of the opponent) does not raise doubts (cf. art. $213 \$ 2$ PCCP), setting up a public hearing just in order to pass a judgment on the merits would be an excessive realization of the right to a public hearing. ${ }^{39}$ The external aspect of this procedural right should make concessions to another procedural value, which under these circumstances manifests itself in ending the proceedings without undue delay ${ }^{40}$ This interpretation does not infringe upon the internal aspect of the right to a public hearing, nor upon the right to a fair trial. ${ }^{41}$

\section{THE GROUNDS FOR PASSING A JUDGMENT IN CAMERA IN THE LIGHT OF A RECENT AMENDMENT OF THE POLISH CODE OF CIVIL PROCEDURE}

The Act of 4 July 2019 widened the spectrum of situations in which the Polish Code of Civil Procedure allows the court to pass a judgment on the merits in camera, i.e. without conducting a public hearing. Examining the case without a public hearing means that the court conducts proceedings in their office (Germ. Kabinettsjustiz) in written proceedings without the participation of the parties and the public. While examining the case outside of a public hearing the court is not obliged to inform the parties of the date of the session, unless the judge summons them to appear before the court. However, most often the parties learn about the outcome of the case when the court serves them with a judgment. ${ }^{42}$ Situations in which the court passes the verdict without holding a public hearing should only happen under exceptional circumstances, because they diverge from the 'right to public hearing' guaranteed under art. 6 (1) ECHR, art. 45

36 Cf. K Flaga-Gieruszyńska, 'Szybkość, sprawność i efektywność postępowania cywilnego - zagadnienia podstawowe' (2017) 3 Zeszyty Naukowe KUL 5 ff; Ereciński, Weitz (n 33) 3 ff.

37 Grzegorczyk, Weitz (n 8) point 113.

38 Cf. Kościółek (n 3) 451-452 and 457-458; A Mendrek, 'Wyrokowanie na posiedzeniu niejawnym zagadnienia wybrane' in T Ereciński, J Gudowski, M Pazdan, Ius est a iustitia appellatum. Księga jubileuszowa dedykowana Profesorowi Tadeuszowi Wiśniewskiemu (WK 2017) 369; Skibińska (n 32) 152; A Jasiecki, 'Wydanie wyroku na posiedzeniu niejawnym na podstawie art. $1481 \mathrm{KPC}$ - uwagi dotyczące nowelizacji Kodeksu postępowania cywilnego' (2016) 17 Monitor Prawniczy 905 ff.; M Sorysz, 'Rozpoznanie sprawy na posiedzeniu niejawnym w postępowaniu cywilnym w świetle zmiany KPC z 10 lipca 2015 r.' (2016) 9 Palestra 82 ff.

39 Kościółek (n 3) 452.

40 See. R Kulski, 'Komentarz do art. $148^{1}$ KPC' in A Marciniak (ed) Komentarz KPC (CH Beck 2019) vol. 1, point 7.

41 Cf. A Łazarska, Rzetelny proces cywilny (WK 2012) 355-356; M Kłopocka, 'Prawo do sądu w orzecznictwie Trybunału Konstytucyjnego' (2007) LXXVI Acta Universitatis Wratislaviensis 'Prawo' 74. Cf. Judgement of the Polish Constitutional Tribunal of 13.5.2002, SK 32/01, OTK-A 2002, no 3, item 31; judgement of the Polish Constitutional Tribunal of 18.2.2009, KP 3/08, OTK-A 2009, no 2, item 9; judgement of the Polish Constitutional Tribunal of 7.12.2010, P 11/09, OTK-A 2010, no 10, item 128.

42 M Kłos, 'Commentary to article 374 PCCP', in A Marciniak (ed.), Kodeks postępowania cywilnego. Komentarz (CH Beck 2019) vol. II, ed. 1, point 6. Cf Grzegorczyk, Weitz (n 8) point 112. 
(1) of the Constitution of the Republic of Poland and article $9 \$ 1$ sentence 1 in principio PCCP and article $148 \$ 1$ in fine PCCP.

Prior to the amendments introduced by the Act of 4 July 2019, the Polish Code of Civil Procedure regulated two cases, in which it was possible to pass a judgment in camera. The first one, article 341 PCCP enables the court to issue a default judgment, if the writ of service on the defendant is delivered to the court within two weeks since the date of the audience at which the defendant was absent. The other one, article $148^{1} \mathrm{PCCP}$, added by the Act of 10 July $2015,{ }^{43}$ concerns a situation in which a) the defendant conceded the claims laid out in the lawsuit or b) when upon filing all the documents by the parties, the court comes to the conclusion that it is not necessary to hold a public hearing. ${ }^{44}$

In regards to further grounds for passing a judgment in camera, the Act of 4 July 2019 introduced changes in article $339 \$ 1$ PCCP and added a new article $191^{1}$ PCCP. According to the new content of article $339 \$ 1$ PCCP such a possibility will present itself, if the defendant does not file a response to the lawsuit in the deadline ordered by the judge. ${ }^{45}$ If the judge fails to inform the defendant about this obligation, the statement of grounds specified in article $339 \$ 1$ PCCP will not be possible. As the lawmaker underlined in the written explanation accompanying the Act of 4 July 2019, the introduction of an obligatory response to the lawsuit caused changes in the set of circumstances, which should be perceived as passivity on the part of the defendant. ${ }^{46}$ Obliging a judge to conduct a public hearing just in order to pronounce the default of the defendant is not an effective solution. Therefore, a judge is allowed to impose consequences from the defendant's passivity as early as possible, provided that the facts presented in the lawsuit do not raise doubts and the plaintiff's claims do not require to be verified. It is worth adding that the discussed regulation does not necessarily require the court to pass a default judgment but rather provides a judge with such a possibility, if the grounds for ending the process seem justified (cf. article $205^{4} \S 1 \mathrm{PCCP}$ ).

The amendment of Article $339 \$ 1$ PCCP was positively evaluated by the Polish doctrine. ${ }^{47}$ It is worth adding that the idea of linking a default judgment with the defendant's failure to file an obligatory response to the lawsuit goes back to the works of the interwar Codification Commission. ${ }^{48}$ The postulate to introduce this regulation in the general part of the PCCP regularly occurred in the course of the doctrinal discussion. ${ }^{49}$ It was

43 Cf the Act of 10 July 2015, Polish Journal of Laws 2015, item 1311 with amendments.

44 Cf Skibińska (n 32) 151 ff; Jasiecki (n 38) 905 ff.; M Bieszczad, 'Dopuszczalność rozpoznania sprawy przez sąd na posiedzeniu niejawnym po nowelizacji - uwagi do przepisu art. $148^{1} \$ 1$ KPC', in I Gil (ed.) Postępowanie cywilne w dobie przemian, Warsaw 2017; Sorysz (n 38 ) 82 ff.; Mendrek (n 38 ) 364 ff.

45 In comparative perspective cf. Art. 223 Swiss ZPO (versäumte Klageantwort); $\$ 331$ (3) German ZPO; $\$ 276$ (1) German ZPO; $\$ 335$ (1) point 4 German ZPO; $\$ 396$ (1) Austrian ZPO; § 397 Austrian ZPO.

46 Cf. the written explanation accompanying the Government's bill on the amendment of the Polish Code of Civil Procedure and other laws, Sejm's legislative materials no 3137, p. 26.

47 Kościółek (n 3) 463-465. Cf. B Kaczmarek-Templin, ‘Commentary to article 339 PCCP’, in J Gołaczyński, D Szostek (eds), Kodeks postępowania cywilnego. Komentarz do ustawy z 4.07.2019 r. o zmianie ustawy - Kodeks postępowania cywilnego oraz niektórych innych ustaw (CH Beck 2019) point 2.

48 FK Fierich, 'Postępowanie przed sądami okręgowemi', in Polska procedura cywilna. Projekty referentów z uzasadnieniem (Cracow 1921) 216.

49 AG Harla, 'Odpowiedź na pozew w projektach Komisji Kodyfikacyjnej II RP i refleksje de lege ferenda', in J Gudowski, K Weitz (eds), Aurea praxis, aurea theoria. Ksiega pamiątkowa ku czci Profesora Tadeusza Erecińskiego (WK 2011) vol 2, p 2983 ff.; AG Harla, 'Odpowiedź na pozew w przyszłym Kodeksie 
often indicated that widening the possibility of issuing a default judgment in camera would have a beneficial effect on the economy and the effectiveness of the proceedings. ${ }^{50}$ Nonetheless, there are some controversial issues connected with the new regulation. For instance, it is not entirely clear why the decision on passing a default judgment is left to the discretionary power of the judge. Hence, it is difficult to explain why under certain circumstances the court might decide to continue the proceedings, even though the defendant defaulted on the obligation to file a response to the lawsuit. Therefore, de lege ferenda it might be suggested that passing a default judgment on the grounds specified in article $339 \$ 1$ PCCP might be conditioned on the request of the plaintiff. Such a solution would eliminate the uncertainty in this regard.

The exclusion of the right to a public hearing is also present in the new article $191^{1}$ PCCP, which allows the court to dismiss the lawsuit a limine at a court session held in camera, if the content of the lawsuit is regarded by the court as manifestly ill-founded. The new legal provision stipulates that the court is not required to serve an manifestly ill-founded lawsuit on the defendant and that it is dismissed from examining the motions put forward by the plaintiff. The same simplified mechanism also applies to the appellate procedure. According to article $391^{1} \$ 1$ PCCP the appellate court is allowed to examine in camera an appeal from the judgment in which the evidently ill-founded lawsuit had been dismissed. In this situation the court is also exempted from serving the appellate measure to the defendant. The cassation is admissible only, if the court of the second instance quashed the judgment in which the lawsuit was deemed as 'manifestly ill-founded', which, in consequence, led to the examination of the case according to the general rules.

In the written explanation accompanying the Act of 4 July 2019, the lawmaker stated that there are many situations in which plaintiffs file evidently groundless lawsuits just to generate needless judicial activity that requires significant time input. Dealing with such cases absorbs the court's energy which could have been dedicated to dealing with the adequately filed lawsuits. ${ }^{51}$ The lawmaker also provided the definition of the 'manifestly ill-founded lawsuit'. In his opinion such a lawsuit has no chances whatsoever to be accepted by the court. Therefore, dealing with it would mean a waste of time for the judicial system. ${ }^{52}$

The abovementioned regulation raises concerns when it comes to its congruency with the constitutional standard of the Republic of Poland. ${ }^{53}$ The questions concern not only the exclusion of the public hearing (art. 45 of the Constitution of the Republic of Poland),

postępowania cywilnego', in K Markiewicz, A Torbus (eds), Postępowanie rozpoznawcze w przyszłym Kodeksie postępowania cywilnego (CH Beck 2014) p. 621-622; Sorysz(n 38) 91; Mendrek (n 38) 377-378.

$50 \quad$ Kaczmarek-Templin (n 47) point 2; Sorysz (n 38) 91; Kościółek (n 3) 464.

51 Cf. the written explanation accompanying the Government's bill on the amendment of the Polish Code of Civil Procedure and other laws, Sejm's legislative materials no 3137, s. 36.

52 The evident groundlessness of the lawsuit takes place when every lawyer, without a thorough analysis of the matter will state that the plaintiff cannot be successful. - see decision of the Polish Supreme Court of 18.01.1966, I CZ 124/65, Legalis; decision of the Polish Supreme Court of 8.10.1984, II CZ 112/84, Legalis. Cf. D Szostek, 'Commentary to art. 191 ${ }^{1}$ PCCP', in J Gołaczyński, D Szostek (eds), Kodeks postępowania cywilnego. Komentarz do ustawy z 4.07.2019 r. o zmianie ustawy - Kodeks postępowania cywilnego oraz niektórych innych ustaw (Legalis 2019) point 2. 
but also other guarantees of the right to a fair trial. First of all, the lawmaker excluded the defendant's right to be heard by curbing procedural guarantees connected with the internal aspect of the right to a public hearing. ${ }^{54}$ These guarantees should be put into effect by informing the defendant about the lawsuit and the outcome of the proceedings. By infringing on this procedural right, the defendant is deprived of the possibility of learning about the lawsuit and taking a stance on it. Even though the Committee of Ministers of the Council of Europe $\mathrm{e}^{55}$ accepts to some extent simplification of procedure with regard to manifestly ill-founded lawsuits, such measures should not infringe upon procedural rights of the parties. Unfortunately, a maximally simplified way of dealing with such lawsuits, like the one adopted by the Act of 4 July 2019, violates the rights to a fair trial not only from the perspective of the plaintiff, but also from the perspective of the defendant.

The Act of 4 July 2019 also introduced amendments for examining an appeal in the court session held in camera. Prior to the enactment of the new law, it was admissible for the court to examine an appeal outside of the public hearing, if a) the plaintiff withdrew the lawsuit, b) the appellant withdrew the appellate measure, $c$ ) if the proceedings were invalid, or d) if the appellate measure was inadmissible (art. 374 sentence 2 in fine PCCP). Under the new law the court will have a new possibility of passing a verdict in camera at its disposal. According to article $374 \$ 1$ sentence 1 in fine PCCP it will encompass a situation when conducting a public hearing is not necessary. Examining this premise will be left to the discretionary power of the court. However, if a party requests the court to conduct a public hearing, the court will be obliged to respect it, unless the circumstances cited in article 374 sentence 2 in fine PCCP (see above) take place.

It ensues from the following that unless a party files a motion for a public hearing, the decision whether to conduct a public session or not, will remain with the appellate court. In the process of taking this decision, the court should take into consideration the type of charges raised in the appellate measure and whether an appellant presented new facts and evidence. If the court of first instance correctly established the facts of the case and the dispute at the appellate level is focused on strictly legal issues connected solely with the interpretation of law, it would be acceptable to examine an appeal in the course of written proceedings. Similarly, if the appellant filed charges with regard to strictly formal or technical issues, such as arithmetic errors, it would also be acceptable to refrain from examining an appeal at the public hearing. It needs emphasizing that the appellate court should also take into account the system of appeal that is regulated in a given procedural system. When it comes to the Polish law, the so-called full appeal and appelatio cum beneficium novorum are adopted, which means that the appellate court's

54 Cf. judgement of the Polish Constitutional Tribunal of 11.06.2002, SK 5/02, OTK-A 2002, no 4, item 41; judgement of the Polish Constitutional Tribunal of 6.12.2004, SK 29/04, OTK-A 2004, no 11, item 114; judgement of the Polish Constitutional Tribunal of 2.10.2006, OTK-A 2006, no 9, item 118.

55 The Committee of Ministers of the Council of Europe has adopted on 28.02.1984 a Recommendation No R (84) 5, in an attachment to which it formulated nine Principles of civil procedure designed to improve the functioning of justice. It indicated: 'When a party brings manifestly ill-founded proceedings, the court should be empowered to decide the case in a summary way and, where appropriate, to impose a fine on this party or to award damages to the other party' $<$ https://rm.coe. int/CoERMPublicCommonSearchServices/DisplayDCTMContent?documentId=09000016804e19b1> accessed 20 February 2020. 
role consists not only of controlling the judgment of the court of the first instance, but also in examining the merits of the case as thoroughly as possible. Therefore, whenever an appellate court carries out evidence proceedings or examines the facts of the case, holding a public hearing should be a rule rather than an exception.

\section{PASSING PROCEDURAL DECISIONS OUTSIDE OF A PUBLIC HEARING}

The Act of 4 July 2019 also widened the scope of strictly procedural decisions (Pol. postanowienia) that can be passed in camera. According to the new rule specified in article $148 \$ 3$ PCCP, every procedural decision (i.e. not: the judgment on the merits) - lege non distinguente and also a decision concerning the evidence proceeding - can be rendered outside of a public hearing. The lawmaker has concluded that this new rule will benefit the economy of the proceedings. It is worth underlining that the standard established by the ECHR, as well as the Constitution of the Republic of Poland with regard to strictly procedural decisions, is more lenient than when it comes to judgments on the merits. Additionally, less emphasis on the external aspect of the right to a public hearing does not adversely affect the internal aspect of this procedural right (i.e. the parties' right to be heard and the right to be informed about the course of the proceedings - cf. Art. $357 \S 2$ and $₫ 2^{1}$ PCCP).

The regulation of the new article $148 \$ 3$ PCCP has sparked divergent reactions in the doctrine. ${ }^{56}$ On a negative note, it was underlined that passing a procedural decision sometimes requires the court to hear the parties. Passing a procedural decision outside of a public hearing is controversial, especially when the court decides about the scope of evidence proceedings. ${ }^{57}$ The Supreme Court even held that establishing the facts of a case on the basis of means of evidence, which has not been formally accepted at the public hearing, infringes on the rules of evidence proceedings, when it comes to the procedural rules of directness, public hearing, equality of the parties and adversarial proceedings. ${ }^{58}$ Prior to the enactment of the Law of 4 July 2019 it was possible only in two cases: firstly, when the court decided about accepting an opinion of an expert (cf. former art. 279 PCCP) and secondly, when it modified its former decision on the evidence proceedings (Pol. postanowienie dowodowe; art. $240 \$ 1$ PCCP).

The specificity of the phase of the proceedings, when the court reaches a decision regarding the scope and means of evidence, makes it highly desirable for the parties to participate directly in this process. A situation, in which the court dismisses a means of evidence in its entirety or in part, has a direct influence on the extent of the evidence proceedings and indirectly exerts an influence on the outcome of the case. Adopting

56 Critically in this regard - cf. A Kościółek, 'Commentary to article 148 PCCP', in T Zembrzuski (ed), Kodeks postępowania cywilnego. Komentarz do zmian (Lex 2019) point 17; K Flaga-Gieruszyńska, 'Commentary to article 148 PCCP', in A Zieliński (ed), Kodeks postępowania cywilnego. Komentarz (Legalis 2019) point 9. Cf a different approach - R Kulski, 'Commentary to article 148 PCCP', in A Marciniak (ed), Kodeks postępowania cywilnego (Legalis 2019) vol 1, point 9; D Markiewicz, 'Commentary to article 148 PCCP', in T Szanciło (ed), Kodeks postepowania cywilnego. Komentarz (Legalis 2019) vol 1, p 7.

57 Cf. in detail A Łazarska, K Górski, 'Commentary to article 236 PCCP', in T Szanciło (ed), Komentarz KPC (Legalis 2019) vol 1, point 20-23.

Cf judgement of the Polish Supreme Court of 20.08.2001, I PKN 571/00, OSNP 2003, no 14, item 330. 
adequate procedural rules at this stage of the judicial decision process is highly significant, when it comes to safeguarding the guarantees of the right to a fair trial (art. 6 ECHR, art. 45 (1) of the Constitution of the Republic of Poland). In the course of the proceedings it is essential to enable the parties to present their stance with regard to the evidence motions of the other party, as well as to call into question (appeal) the scope of evidence proceedings which was ordered by the court (art. 236 PCCP).

On a positive note, the new article $148 \$ 3$ PCCP contributed to unifying the rules of passing procedural decisions. Prior to the enactment of the Act of 4 July 2019 these rules were scattered throughout the Polish Code of Civil Procedure and many procedural situations were unnecessarily regulated in multiple provisions. It is worth mentioning that article $148 \$ 3$ PCCP does not prevent the court from issuing procedural decisions at the public hearing, leaving the judge a discretionary possibility in this regard.

\section{CONCLUSION}

In conclusion the right to a public hearing does not necessarily need to be guaranteed in equal measure at all stages of civil proceedings. In the course of a civil process one can point at many situations and many procedural activities, which not only can but also should be performed in camera. It contributes to a more effective organization of the proceedings and it benefits the economy of judicial action. Therefore, some amendments introduced to the Polish civil procedure by the Act of 4 July 2019 are worth praising, as they help to speed up the civil process in a good way. Others are more controversial as they overlook important aspects of the right to a fair and public hearing. The legislator should always keep in mind that the parties to the proceedings are interested in a transparent judicial process. ${ }^{59}$ Therefore, adjudicating the case in camera (Germ. Kabinettjustiz) should be regarded as an exception to the rule. The right to a fair trial, as well as public control over it, constitute an indispensable element of the proper functioning of judicial system.

59 As JF du Tremblay stated, 'The justice is the creation of light, not darkness' - citing Waśkowski (n 3) 154. 